\title{
Potential of condensed tannins for the reduction of emissions of enteric methane and their effect on ruminant productivity
}

\author{
Potencial de los taninos condensados para reducir las emisiones de metano entérico \\ y sus efectos en producción de rumiantes \\ AT Piñeiro-Vázquez ${ }^{a *}$, JR Canul-Solís ${ }^{\mathrm{a}}$, JA Alayón-Gamboa ${ }^{\mathrm{b}}$, AJ Chay-Canul ${ }^{\mathrm{c}}$, AJ Ayala-Burgos ${ }^{\mathrm{a}}$, \\ CF Aguilar-Pérez ${ }^{\text {a }}$ FJ Solorio-Sánchez ${ }^{\text {a }}$, JC Ku-Vera ${ }^{\mathrm{a}}$ \\ aFacultad de Medicina Veterinaria y Zootecnia, Universidad Autónoma de Yucatán, Yucatán, México.

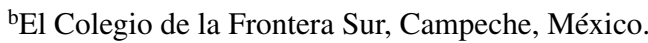 \\ 'División Académica de Ciencias Agropecuarias, Universidad Juárez Autónoma de Tabasco, Tabasco, México.
}

\begin{abstract}
RESUMEN
El metano $\left(\mathrm{CH}_{4}\right)$ es un gas subproducto de la fermentación de los carbohidratos en el rumen. La agricultura contribuye con el $47 \%$ de las emisiones antropogénicas de $\mathrm{CH}_{4}$, siendo los rumiantes responsables del 39\% de las emisiones de metano entérico. Este gas de efecto invernadero (GEI) tiene un potencial de calentamiento global 25 veces más que el $\mathrm{CO}_{2}$ y representa una pérdida de hasta el $12 \%$ de la energía total consumida por los rumiantes. Este trabajo describe los mecanismos de acción de los taninos condensados contenidos en follajes y frutos y su efecto en los microbios del rumen, así como su potencial en la mitigación de las emisiones de $\mathrm{CH}_{4}$. Los hallazgos sugieren que los taninos condensados reducen la población de protozoos hasta 79\%, reduciendo además los metanogenos del rumen hasta en 33\%. Los taninos condensados se unen a proteínas y polisacáridos formando complejos, reduciendo así la digestibilidad de la metería seca y orgánica y la producción de $\mathrm{H}_{2}$ metabólico, el que es usado por metanogenos para la reducción del $\mathrm{CO}_{2}$ a $\mathrm{CH}_{4}$. Estudios in vitro sugieren que los taninos condensados pueden reducir el $\mathrm{CH}_{4}$ en el rumen hasta $63 \%$, mientras que in vivo se han registrado reducciones hasta $58 \%$ en la producción de $\mathrm{CH}_{4}$. Además, la incorporación de taninos condensados en la ración de rumiantes tiene el potencial de aumentar la ganancia de peso en $26 \%$, relacionando esto al aumento en el flujo de proteína de baja degradación ruminal al intestino delgado o la reducción de la energía perdida en forma de $\mathrm{CH}_{4}$ en el rumen. Se concluye que la incorporación de taninos condensados en la ración de los rumiantes en concentración de 3-6\% de materia seca puede reducir las emisiones de $\mathrm{CH}_{4}$ así como mejorar la ganancia de peso y producción de leche de los animales productivos.
\end{abstract}

Palabras clave: metano, gas de efecto invernadero, taninos condensados, leguminosas tropicales.

\section{SUMMARY}

Methane $\left(\mathrm{CH}_{4}\right)$ gas is a by-product of anaerobic fermentation of carbohydrates in the rumen of ruminant species. Agriculture contributes with $47 \%$ of anthropogenic emissions of $\mathrm{CH}_{4}$, being the ruminants responsible for $39 \%$ of enteric emissions of $\mathrm{CH}_{4}$. This greenhouse gas (GHG) has twenty-five times higher global warming potential than $\mathrm{CO}_{2}$ and represents a loss of up to $12 \%$ of the gross energy consumed by ruminants. The aim of this review is to describe the mechanisms of action of condensed tannins contained in foliage of trees and shrubs, and their effect on rumen microbes, as well as their potential for mitigation of $\mathrm{CH}_{4}$ emissions. The findings suggest that condensed tannins reduce protozoa population up to $79 \%$ and along with this, rumen methanogens are decreased by up to $33 \%$. Condensed tannins bounded to proteins and polysaccharides of the ration form complexes which reduce digestibility of dry and organic matter and production of metabolic $\mathrm{H}_{2}$, used by methanogens to reduce $\mathrm{CO}_{2}$ to $\mathrm{CH}_{4}$ In vitro studies suggest that condensed tannins may reduce rumen $\mathrm{CH}_{4}$ up to $63 \%$ in vitro and up to $58 \%$ in vivo. Additionally, incorporation of condensed tannins in the ration of ruminants might increase weight gain by $26 \%$, maybe due to the increase in the flow of protein of low rumen degradability to the small intestine or to the reduction of energy losses as $\mathrm{CH}_{4}$ in the rumen. It is concluded that incorporation of condensed tannins in the ration of ruminants at 3-6\% of dry matter concentrations can reduce $\mathrm{CH}_{4}$ emissions as well as to improve weight gain and milk yield of productive animals.

Key words: methane, greenhouse gases, condensed tannins, tropical legumes.

\section{INTRODUCTION}

The growth of the human population, mainly in developing countries, will impact on the increasing demand of livestock products such as meat and milk and in the growth of the inventories of ruminant animals (Eckard et al 2010).

Accepted: 16.04 .2015 .

* pineiroiamc@gmail.com
These factors will exacerbate the emissions of methane $\left(\mathrm{CH}_{4}\right)$ to the atmosphere if strategies for mitigation are not devised and applied (Gerber et al 2013). Every year, 80 million tons of $\mathrm{CH}_{4}$ are produced in the world (Eckard et al 2010), agriculture contributes with $47 \%$ of those emissions being the ruminants responsible for $39 \%$ of that (Gerber et al 2013).

$\mathrm{CH}_{4}$ is one of the by-products of anaerobic fermentation of structural carbohydrates in the rumen and along with 
carbon dioxide $\left(\mathrm{CO}_{2}\right)$ and nitrous oxide $\left(\mathrm{N}_{2} \mathrm{O}\right)$, represent the main greenhouse gases $(\mathrm{GHG})$ produced by ruminants (Moss et al 2000). $\mathrm{CH}_{4}$ has a global warming potential twenty-five times greater than that of $\mathrm{CO}_{2}$.

Within the livestock sector, ruminants are the main source of emission of $\mathrm{CH}_{4}$ and their production represents a loss of between 2 to $12 \%$ of the gross energy consumed, being these losses greater in ruminants fed tropical grasses, because of the low digestibility during some seasons of the year, which induce a lower rate of passage and longer time of retention in the rumen, which lead to an increase in the emissions of methane (Johnson and Johnson 1995; Kennedy and Charmley 2012).

However, in the tropics there is diversity of plants that due to its good nutritive value hold potential for ruminant feeding (Bhatta et al 2013 ${ }^{\text {a }}$, additionally several of those plants possess condensed tannins (CT), which have the ability to modify rumen fermentation due to their different mechanisms of action on rumen microorganisms (Tavendale et al 2005) and on the structural components of rations, thus decreasing emissions of enteric methane.

The state of knowledge on mechanisms of action of condensed tannins from foliages of trees and shrubs, and their effects on rumen microbes, animal performance, and their potential to mitigate emissions of methane are dealt with in this review.

\section{RUMINAL METHANOGENESIS}

During the process of anaerobic fermentation of soluble and structural carbohydrates of the ration in the rumen, volatile fatty acids (VFA's) and other by-products are formed, among them: $\mathrm{H}_{2}, \mathrm{CO}_{2}$ and $\mathrm{CH}_{4}$ these last two are known as greenhouse gases (GHG) (Moss et al 2000), being $\mathrm{CH}_{4}$ the most studied due to its greater potential as GHG and to the amount of energy lost $(55.2 \mathrm{MJ} / \mathrm{kg}$ $\mathrm{CH}_{4}$ ) in ruminant species (Brouwer 1965, Johnson and Johnson 1995).

Of the total amount of methane produced daily, 95\% is synthesised in the rumen and the remaining $5 \%$ in the caecum. Methane production is mainly influenced by the type and quality of the ration, for example rations rich in starch (i.e. concentrates) yield lower $\mathrm{CH}_{4}$ emissions (Hales et al 2014) due to the synthesis of propionic acid and to the improvement in the ratio of methane:organic matter fermented in the rumen, compared to rations based on cellulose and lignin (i.e. forages) (Kennedy and Charmley 2012), which favour the synthesis of acetic acid and the production of $\mathrm{H}_{2}$ which is used to reduce $\mathrm{CO}_{2}$ to $\mathrm{CH}_{4}$.

Metabolic $\mathrm{H}_{2}$ present in the rumen is used by the methanogenic bacteria, particularly by the Archaea, which use $\mathrm{H}_{2}$ to reduce $\mathrm{CO}_{2}$ to $\mathrm{CH}_{4}$ (Czerkawski 1986). Some authors have mentioned that there are two main pathways for the synthesis of $\mathrm{CH}_{4}: \mathrm{CO}_{2}+4 \mathrm{H}_{2} \rightarrow \mathrm{CH}_{4}+2 \mathrm{H}_{2} \mathrm{O}$ and $\mathrm{CH}_{3} \mathrm{COO}^{-}+\mathrm{H}^{+} \rightarrow \mathrm{CH}_{4}+\mathrm{CO}_{2}$ (Czerkawski 1986), those pathways use $\mathrm{H}_{2}$ as an intermediary in the reduction of
$\mathrm{CO}_{2}$ to $\mathrm{CH}_{4}$, in anaerobic conditions. These processes are controlled by means of the reduction of cofactors such as nicotinamide adenine dinucleotide reduced (NADH); NAD phosphate reduced (NADPH) and flavin adenine dinucleotide reduced $(\mathrm{FADH})$, which are oxidized to $\mathrm{NAD}^{+}, \mathrm{NADP}^{+}$ and $\mathrm{FAD}^{+}$which in turn donate $\mathrm{H}^{+}$ions to synthesise $\mathrm{H}_{2}$ (Martin et al 2010; Kittelmann and Janssen 2012).

Rumen protozoa also represent an important factor in methane synthesis, since they live in symbiosis with the Archaea with whom there may be an interspecific transfer of $\mathrm{H}_{2}$ (Johnson and Johnson 1995), rumen defaunation and therefore of the population of methanogens, leads to a reduction of the emission of enteric methane (Puchala et al 2012).

\section{METHANE EMISSIONS FROM RUMINANTS}

Ruminants are the main source of methane arising from the agricultural sector, in this sense Eckard et al (2010) reported that cattle produce around 120 to $450 \mathrm{l} / \mathrm{day}$ of methane and sheep may produce between 20 to $551 /$ day depending on dry matter intake (DMI).

Some studies point out that ruminants produce around $39 \%$ of anthropogenic emissions being cattle responsible for $77 \%$ of that amount, buffalos $13 \%$ and small ruminants 10\% (Gerber et al 2013). McMichael et al (2007) suggested that ruminants fed in extensive systems (grass) produce higher $\mathrm{CH}_{4}$ emissions ( $1.8 \times 10^{9}$ of $\mathrm{CO}_{2}$-equivalents $)$ compared to cattle fed in intensive (grain) systems $\left(0.4 \times 10^{9}\right.$ of $\mathrm{CO}_{2}$-equivalents). On the other hand, Gerber et al (2013) suggested that beef production contributes with 2.9 and milk production with 1.4 Gigatons of $\mathrm{CH}_{4}$.

The emissions of $\mathrm{CH}_{4}$ above described may be augmented due to the increase in human population (9.5 billion for 2050) which will elicit an increase in the demand of milk and meat (73 and 58\% respectively), this will in turn determine an increase in livestock inventories at the global level (Robinson et al 2011). In this way, it has been predicted that emissions of $\mathrm{CO}_{2}, \mathrm{CH}_{4}$ and $\mathrm{N}_{2} \mathrm{O}$, will follow the same pattern of growth, as it was observed in 1996 when the world emissions of $\mathrm{CH}_{4}$ reached $65,000 \mathrm{Gg}$ (equivalents to $\mathrm{CO}_{2}$ ) while in 2011 the emissions of $\mathrm{CH}_{4}$ increased to $92,000 \mathrm{Gg}^{1}$ (FAOSTAT 2011). Due to this increase in the inventories of $\mathrm{CH}_{4}$, a series of strategies have been developed to decrease emissions of $\mathrm{CH}_{4}$, among them: the search for more efficient breeds of livestock (Bezerra et al 2013), rumen defaunation with secondary metabolites (tannins and saponins), the use of various additives and inmunizations, the use of halogenated compounds and organic acids (Kumar et al 2014). However, the use of secondary metabolites (tannins and saponins) is one

\footnotetext{
1 Food and Agriculture Organization of the United Nations (FAOSTAT); 2011. Disponible en http://faostat.fao.org/site/291/default. aspx. Accesed on April 10, 2013.
} 
of the most appropiate method due to their abundance in tropical plants at a small cost.

\section{PLANTS CONTAINING CONDENSED TANNINS USED IN RUMINANT FEEDING}

In different areas of the world there exist a wide diversity of plant species both trees and shrubs, which possess components of defense against herbivores, which are known as secondary metabolites, being the condensed tannins (CT) an important example of such metabolites which are found in foliages, fruits and cortex of plants (Perevolotsky 1994).

In addition to their high crude protein content (10-25\%) and good digestibility (50-60\%) (table 1), plants rich in condensed tannins have the capacity to reduce bacterial and protozoal populations in the rumen and the emissions of $\mathrm{CH}_{4}$ (Puchala et al 2012), furthermore, condensed tannins have the ability to create complexes with the polysaccharides and proteins thus increasing the amount of protein of low rumen degradability which flow to the small intestine, favouring the increase in daily live weight gain and milk production (Min et al 2006).

\section{CONDENSED AND HYDROLYZABLE TANNINS}

Even when tannins are substances not very well defined from the chemical point of view, they belong to the family of the polyphenols, which are characterised by a large number of phenolic compounds, and their molecular weight ranges from 500 to 20,000 daltons (Karus et al 2003).

Condensed tannins (CT) have a strong affinity for other molecules and have the ability to precipitate alkaloids, carbohydrates and proteins. CT are widely distributed in the plant kingdom, and are used as defense against predators, pathogens and competitors and sometimes act in primary metabolism (Harborne 1993).

Conventionally, tannins are classified in two main groups: condensed tannins (CT) and hydrolyzable tannins
(HT). Condensed tannins or proanthocyanidins are formed by polymers of chatequins, leucoanthocyanidins and its derivatives, joined by bonds $\mathrm{C}-\mathrm{C}$ or $\mathrm{C}-\mathrm{O}-\mathrm{C}$, while hydrolyzable tannins are composed of a nucleus formed with a glucid, and its hydroxilated compounds may be esterified by polymers of galic acid, egalic acid, fecarboxilyc acid or of hexahydrodiphenyl acid, on the other hand, when condensed tannins are consumed by the animals, they are no toxic as compared to hydrolyzable tannins, which are degraded by the microorganisms and absorbed as pyrogallol (Reed 1995).

\section{EFFECTS OF CONDENSED TANNINS IN RUMINANTS}

Condensed tannins have been related to several positive effects in animal production (Min et al 2006); however, when they are consumed by ruminants they could produce a variety different effects, one the main being the formation of complexes with proteins and polysaccharides, which are formed in the mouth at $\mathrm{pH} 7$, and those complexes are kept as such while in the rumen until they are dissociated in the abomasum at pH between 3-3.5 (Kumar 1984).

The factors which promote the formation of complexes include: their high molecular weight and the structural flexibility of CT; the bond between the condensed tannin and proteins reduce rumen degradability and increase therefore the flow of protein to the small intestine (Soltan et al 2012).

In spite of their beneficial effects linked to the increase in the flow of protein of low rumen degradability to the small intestine, CT may reduce voluntary intake (VI) and rumen metababolism, and these responses will obey to the doses of condensed tannins, for example when intake of condensed tannins is above $7 \%$ of the DM of the ration, VI is reduced and deleterious effects may occur in animals. However, moderate intakes of condensed tannins (3-6\% of $\mathrm{DM}$ on the ration) may lead to positive responses, such as the formation of the complex between tannin-protein and

Table 1. Chemical composition of plants foliages containing condensed tannins.

Composición química de follaje de plantas que contienen taninos.

\begin{tabular}{|c|c|c|c|c|c|c|}
\hline \multirow{2}{*}{ Species } & $\mathrm{CP}$ & $\mathrm{NDF}$ & $\mathrm{ADF}$ & $\mathrm{CT}$ & TP & \multirow{2}{*}{ Reference } \\
\hline & \multicolumn{5}{|c|}{ Composition in $\%$} & \\
\hline Lespedeza cuneata & 10.3 & 40.1 & 39.9 & 20.0 & - & Puchala et al 2005 \\
\hline Guazuma ulmifolia & 10.4 & 42.5 & 29.5 & 4.7 & 2.8 & Gómez-Castro et al 2006 \\
\hline Acacia farneziana & 24.0 & 42.1 & 26.7 & 4.5 & 10.0 & Gómez-Castro et al 2006 \\
\hline Swietenia mahagoni & 11.2 & 28.1 & 22.2 & 8.6 & 20.7 & Jayanegara et al 2011 \\
\hline Myristica fragans & 10.1 & 38.0 & 36.1 & 7.2 & 18.1 & Jayanegara et al 2011 \\
\hline Prosopis juliflora & 17.9 & 49.4 & 38.4 & 0.04 & 2.9 & Soltan et al 2012 \\
\hline Acacia saligna & 13.8 & 46.5 & 42.8 & 6.3 & 9.1 & Soltan et al 2012 \\
\hline Leucaena leucocephala & 23.6 & 78.9 & 51.1 & 2.3 & 5.17 & Soltan et al 2013 \\
\hline
\end{tabular}

$\mathrm{CP}=$ Crude protein $; \mathrm{NDF}=$ Neutral detergent fibre; $\mathrm{ADF}=$ Acid detergent fibre $\mathrm{CT}=$ Condensed tannins $; \mathrm{TP}=$ Total phenols . 
tannin-carbohydrate, in addition to their anti-parasitic effect (Barry and Duncan 1984) and reduction of $\mathrm{CH}_{4}$ emissions.

\section{EFFECTS OF CONDENSED TANNINS IN THE RUMEN SYNTHESIS OF VOLATILE FATTY ACIDS (VFA'S)}

Condensed tannins have the ability to reduce the fermentation and digestibility of organic matter in the rumen, they also alter the proportions of VFA's, particularly the ratio acetate:propionate; and the presence of $\mathrm{CT}$ may reduce the $\mathrm{NH}_{3}$ production in the rumen (Jayanegara et al 2012, Hassanat and Benchaar 2013).

Under in vitro conditions, Hassanat and Benchaar (2013) demonstrated that CT of Acacia mearnsii and Schinopsis balansae increase the molar proportion of propionate above $100 \mathrm{~g} / \mathrm{kg}$ dry matter, while the proportion of acetic acid goes unaffected. Gurbuz (2009) evaluated the effect of legumes and observed that the total concentration of VFA's was numerically decreased in relation to the concentration of CT of the forage legumes, but the molar proportion of acetate and propionate remained unaffected.

The consistency in the reduction of VFA's production and the relatively constant ratio acetate:propionate seem to depend on the type of vegetation used. Tiemann et al (2008) found that the concentration of the three main VFA's decreased as the concentration of condensed tannins was increased, however, the reduction in VFA's was affected by the source of CT. Concentration of acetate was less affected by the CT of Flemingia macrophylla compared to those of other legumes; however, concentration of propionate was higher with CT from F. macrophylla and Leucaena leucocephala than with those of Calliandra calothyrsus.

Soltan et al (2012) evaluated four plants rich in CT and determined that the molar proportion of acetate was not significantly different among plants, while the concentration of propionate was higher with a reduction in the ratio acetate:propionate with Prosopis juliflora and $L$. leucocephala, This suggests that the effect of the CT in L. leucocephala on the molar proportions of VFA's, will depend on the concentration used.

\section{EFFECTS OF CONDENSED TANNINS ON RUMEN MICROORGANISMS AND THE REDUCTION OF ENTERIC METHANE EMISSIONS}

Even when the specific effect of CT on the reduction in emissions of $\mathrm{CH}_{4}$ is unknown, some authors have pointed out that they form complexes with dietary proteins and carbohydrates in the rumen $(\mathrm{pH}=7.0)$ thus reducing digestibility of DM and organic matter (OM) and the release of $\mathrm{H}_{2}$ (indirect effect) (Jayanegara et al 2011, Patra 2014). Furthermore, CT have the ability to reduce the activity of the protozoa population (Galindo et al 2008) and the bacteria (Archaea) in the rumen, particularly of the population of
Methanobrevibacter ruminantium (Tavendale et al 2005) and Methanosphaera spp (Min et al 2014).

Some authors have pointed out that there are three mechanisms of action of CT on rumen microorganisms (inhibition of enzymatic activity, lack of substrate and direct action on the cell membrane and lack of metallic ions) (McSweeney et al 2001), these effects constraint growth and activity of the rumen population (Goel et al 2005); however, even when partially unknown, some reports indicate that there are bacterial populations with the ability to degrade tannins and to develop enzymatic mechanisms to avoid the microbial effect of tannins (Goel et al 2007). Due to the antimicrobial mechanisms it is possible that the protozoa, bacterial and fungi populations may adapt to the presence of tannins in the ration and the effects of these on methane reduction may be reduced or may only show their effect during a short period of time before the microorganism become adapted to the mechanisms of tannin action (Wischer et al 2014).

Nonetheless, Galindo et al (2008) found that when $L$. leucocephala was included at the level of $30 \%$ under in vitro conditions, there was a reduction in the protozoa and bacterial populations by 39.42 and $43.8 \%$ respectively; similar results were reported by Bhatta et al $\left(2013^{\mathrm{a}}\right)$ who found a reduction of up to $53.5 \%$ in the population of rumen protozoa.

Under in vitro conditions Goel et al (2008) registered a reduction of 44 and $47 \%$ in the rumen population when they added $66 \mathrm{mg}$ of Sesbania sesban and Trigonella foenun-graecum $L$. to the basal susbstrate. Cieslak et al (2012) reduced by $23 \%$ rumen protozoal population when they included $2 \mathrm{~g}$ of CT/kg DM in cows fed forage and concentrate.

In addtion to the reduction in the protozoal population, CT exert important effects on the population of methanogenic bacteria, on this respect it has been found that their incorporation results in a reduction in Methanobrevibacter ruminantium (Tavendale et al 2005). Min et al (2014) observed that when they fed goats with a ration with $30 \%$ of $\mathrm{DM}$ as pine cortex $(10.3 \% \mathrm{CT})$, there was a reduction of 33 and $37 \%$ in bacteria of the genus Methanosphaera spp and Methanobacteriaceae spp respectively.

Under in vitro conditions, Min et al (2006) found that the incorporation of $2 \%$ of CT in the DM from extract of quebracho (with $75 \%$ of CT $\mathrm{kg} / \mathrm{DM}$ ), reduced $\mathrm{CH}_{4}$ production by $31 \%$. Also, Goel et al (2008) reported a reduction of $19.9 \%$ in $\mathrm{CH}_{4}$ production when they added $150 \mathrm{mg}$ of Carduus pynochepalus to the substrate.

Tan et al (2011) found a linear reduction in gas production and when they included condensed tannins from L. leucocephala, gas production was reduced up to $43 \%$, in a similar way $\mathrm{CH}_{4}$ production was decreased by $63 \%$. Jayanegara et al (2011) evaluated gas production with plants containing condensed tannins and found that Swietenia mahagoni, L. leucocephala and Acacia magnium had the ability to reduce $\mathrm{CH}_{4}$ production by $78.3,43.4$ and $65 \%$ 
respectively. Similar results were found by Delgado et al (2012) when evaluating twelve plants rich in condensed tannins, who observed a lower production of $\mathrm{CH}_{4}$ when they were compared to Cynodon nlemfuensis. Table 2 describes several studies that demonstrate the potential of condensed tannins for the reduction of $\mathrm{CH}_{4}$ emissions under in vitro conditions.

Under in vivo conditions, Puchala et al (2005) found a reduction of $57.1 \%$ in $\mathrm{CH}_{4}$ emissions in the rumen of goats consuming $L$. cuneata compared to goats that had consumed only grass (table 3 ). On the other hand Animut et al (2008) reported that goats consuming 200, 447and $613 \mathrm{~g}$ DM of $L$. striata were able to reduce $\mathrm{CH}_{4}$ emissions by $32.8,47.3$ and $58.4 \%$; respectively. Dias-Moreira et al (2013) observed that when they included $40 \mathrm{~g} / \mathrm{kg}$ DM of condensed tannins from L. leucocephala in the ration of Santa Inés sheep, emissions of $\mathrm{CH}_{4}$ were reduced by $26 \%$. Similar results were reported by Bhatta et al $\left(2013^{\mathrm{a}}\right)$ when they added $1.8 \mathrm{~g}$ of CT $+3.8 \mathrm{~g}$ of HT (per $\mathrm{kg} \mathrm{DM}$ ) in the ration of goats, observing that methane production decreased by $22 \%$, this effect being correlated with the reduction in the digestibility of organic matter $(13.5 \%)$ and the lower concentration of acetic acid (17\%) in the rumen.

In our laboratory, we fed cattle Pennisetum purpureum grass mixed with increasing levels of L. leucocephala (containing 1.5\% CT) at levels of 40,60 and $80 \%$ and using open-circuit respirations chambers, reductions in methane emissions of 18, 22 and $34 \%$ respectively have been obtained (Piñeiro-Vázquez, unpublished data). At this respect, Delgado et al (2012) observed that when they included $27 \%$ of L. leucocephala in the ration of sheep, $\mathrm{CH}_{4}$ emissions decreased by $15.6 \%$. Tiemann et al (2008) included $300 \mathrm{~g} / \mathrm{kg}$ of DM as foliage of C. calothyrsus or F. macrophylla in the ration of growing sheep and recorded a reduction of 21 and $17.4 \%$ in the production of enteric $\mathrm{CH}_{4}$, this reduction could have been caused by the decrease in organic matter digestibility of 8.3 and $11.5 \%$ respectively. Table 3 shows the effect of condensed tannins on the reduction of enteric $\mathrm{CH}_{4}$ under in vivo conditions.

In a meta-analysis published by Jayanegara et al (2012), it was conclusively demonstrated that a clear relationship exist between the concentration of $\mathrm{CT}$ in the ration, and the reduction in the synthesis of enteric $\mathrm{CH}_{4}$, which agrees with reports by several other authors (Bhatta et al 2013a, Soltan et al 2013).

Even when the precise mechanism of action of CT on methanogenesis has not been clearly established both under in vitro as under in vivo conditions (tables 2 and 3), CT have demonstrated potential for the reduction of $\mathrm{CH}_{4}$, part of this reduction in $\mathrm{CH}_{4}$ synthesis is due to the formation of the tannin-protein and tannin-polysaccharide complexes. Huang et al (2011) found that the reduction in the emissions of $\mathrm{CH}_{4}$ is closely related to the molecular weight of the CT involved. Naumann et al (2013) indicated that the difference in molecular weights does not affect $\mathrm{CH}_{4}$ production, however they demonstrated that concentrations of $\mathrm{CT}$ had a direct effect on the reduction of $\mathrm{CH}_{4}$ production in the rumen.

Still, Hatew et al (2014) evaluated different cultivars of Onobrychis viciifolia and found that the effect of this plant it is not only due to the concentration of CT, but rather to different associated components, among them the content of micronutrients and to the different molecular structures of tannins.

In the different experiments discussed in this review, several foliage of trees or shrubs have been employed as sources of secondary metabolites (condensed tannins), which have shown an effect on the reduction of methane emissions, in this context, it is important to know the potential of silvopastoral systems (Murgueitio et al 2013), as well as the inclusion of foliages and fruits which contain condensed and hydrolyzable tannins and saponins as an strategy for the mitigation of the emissions of greenhouse gases, specifically for the reductions of enteric $\mathrm{CH}_{4}$. Additionally to the effect on the reduction of the emissions of greenhouse gases, it is important to assess the potential of silvopastoral systems to increase production of meat and milk in order to decrease rate of emission of GHG per unit product $\left(\mathrm{g} \mathrm{CH}_{4} / \mathrm{kg}\right.$ milk or $\mathrm{g}$ of $\mathrm{CH}_{4} / \mathrm{kg}$ live weight).

\section{EFFECTS OF CONDENSED TANNINS ON ANIMAL PERFORMANCE}

Condensed tannins exert a beneficial effect on daily weight gain probably due to the fact that they protect dietary protein from microbial degradation in the rumen which increases the absorption of amino acids from the small intestine (Min et al 2006, Soltan et al 2012).

The relatively lower degradability of dietary protein in the rumen has been widely demonstrated in plants which contain high concentrations of condensed tannins. In this sense, Soltan et al (2012) found that with L. leucocephala in a concentration of $46 \mathrm{eq}-\mathrm{g}$ of tannic acid/ $\mathrm{kg} \mathrm{DM}$ of condensed tannins compared to a grass without tannins, rumen protein degradation was reduced from 614 to $117 \mathrm{~g} /$ $\mathrm{kg}$ of DM, while rumen undegradable protein was increased from 386 to $888 \mathrm{~g} / \mathrm{kg}$ DM. These authors also showed that digestible protein in the small intestine increased from 416 to $464 \mathrm{~g} / \mathrm{kg} \mathrm{DM}$, this increase in undegradable protein was in turn correlated with the increase in the excretion of nitrogen in the faeces. The influence of CT on the nitrogen balance has been reported. In this regard, Soltan et al (2013) determined that with rations containing 8.8 eq-g tannic acid/kg DM, the amount of nitrogen in feces increased by $70.19 \%$, while urinary nitrogen decreased by $12.9 \%$. Similar results were reported by Carulla et al (2005) when they fed sheep with extracts from A. mearsii observing an increase in nitrogen content of faeces, as well as a reduction of $9 \%$ in the proportion of total nitrogen excreted in urine. A similar trend was also observed by Chung et al (2013) in steers fed sainfoin containing 2.4\% 


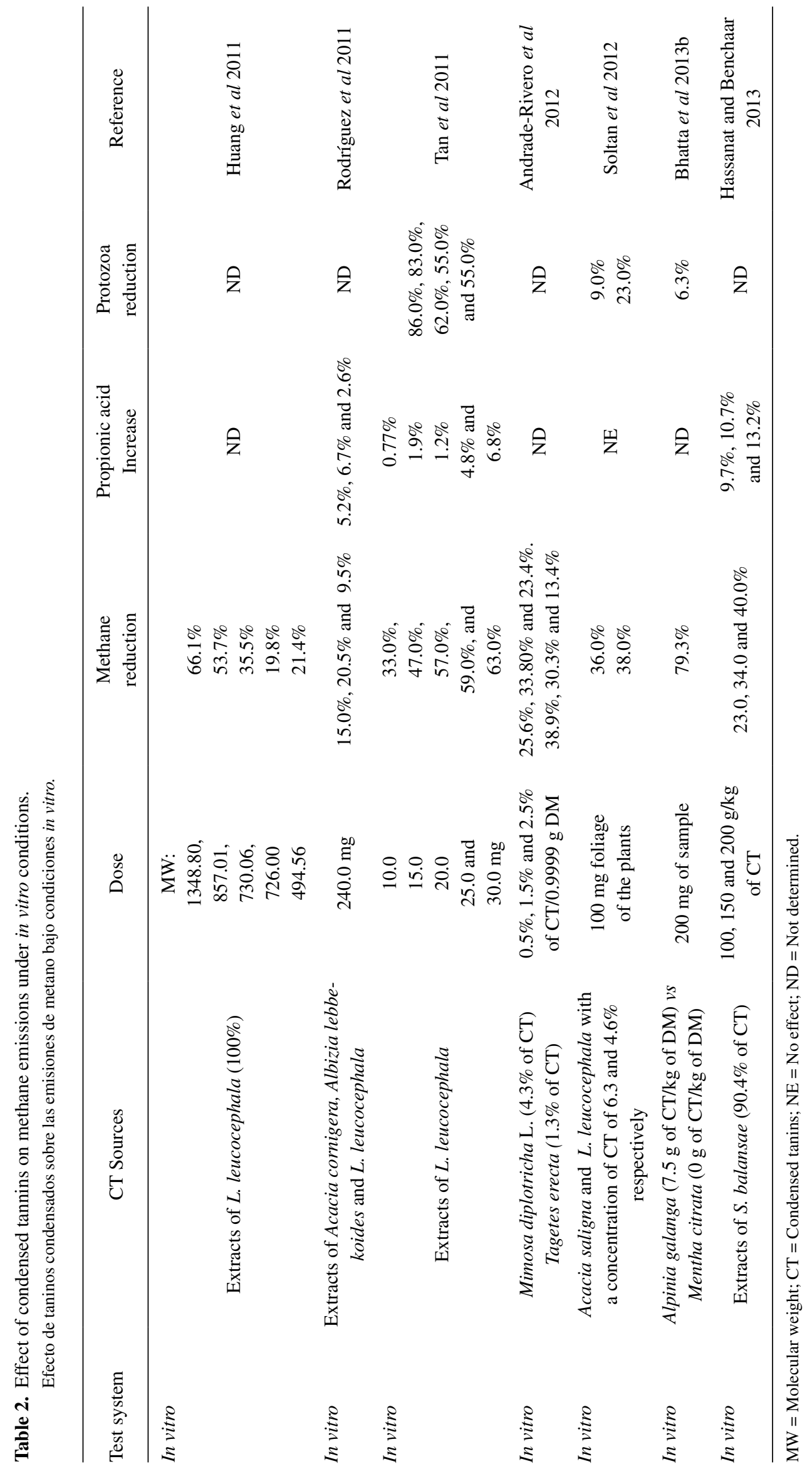


METHANE, GREENHOUSE GASES, CONDENSED TANNINS, TROPICAL LEGUMES

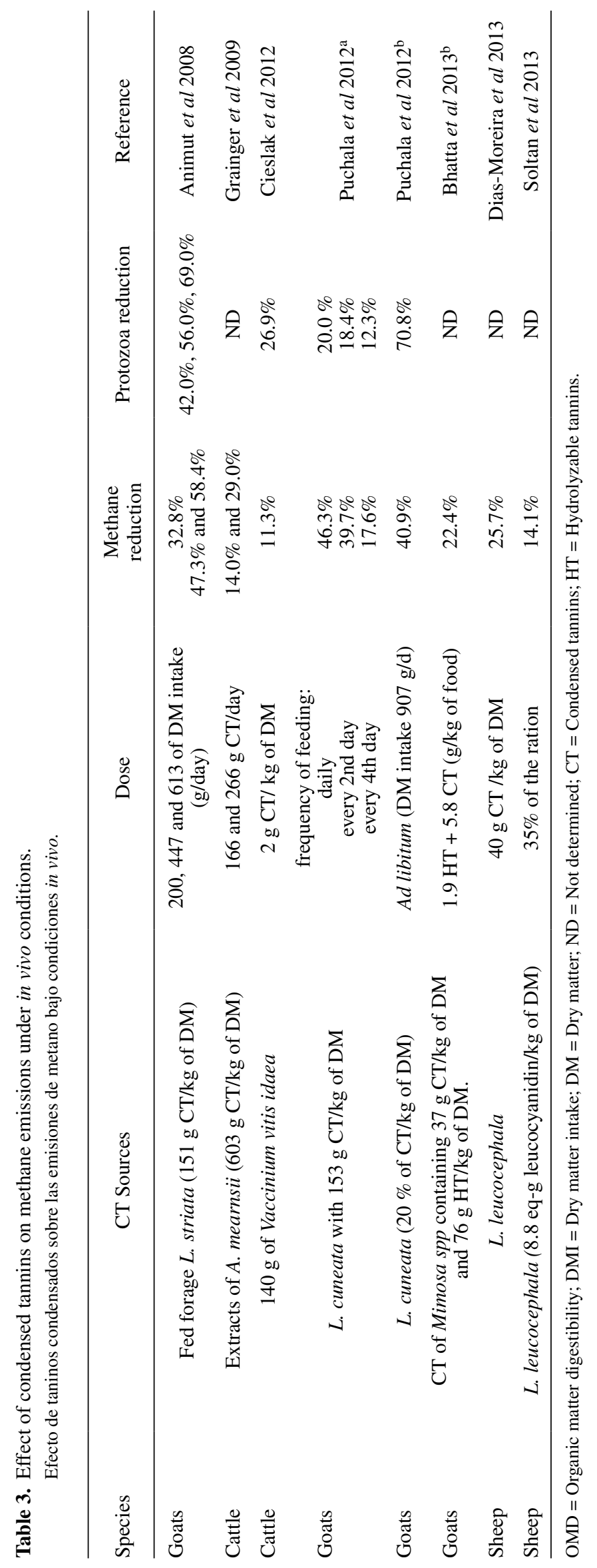


of condensed tannins in which protein digestibility was reduced by $7 \%$.

Some studies have indicated that CT exert a beneficial effect on daily weight gain; Min et al (2006) fed steers with $2 \%$ condensed tannins from quebracho (Chemtan Company Inc., Exeter, NH; extract contains approximately $75 \% \mathrm{CT}$ in the dry matter) and obtained an increase of $20.8 \%$ in live weight gain; similarly Ayala-Monter (2013) reported that when they added $2.5 \%$ condensed tannins in the ration, daily weight gain increased by $5.5 \%$. This could be due to the effect of condensed tannins on the reduction of rumen degradable protein (Soltan et al 2012), promoting its pass to the abomasum, where proteins are digested, and the amino acids released are absorbed further down the alimentary tract in the small intestine.

Burke et al (2014) obtained an increase in daily weight gain of $26.1 \%$ in grazing sheep supplemented with $900 \mathrm{~g}$ of $L$. cuneata compared to a group of sheep supplemented with $900 \mathrm{~g}$ of a concentrate with $16 \%$ crude protein. Min et al (2012) included $1.5 \%$ of CT from A. mearnsii in the ration of cattle and they did not find differences in weight gains between treatments. Nonetheless, some studies have reported reductions in daily weight gain of sheep (135 vs $48 \mathrm{~g} /$ day), when they were fed corn and $2.5 \% \mathrm{CT}$ in the ration (Priolo et al 2000). This reduction in daily weight gain may have been due to the reduction in voluntary feed intake, digestibility of organic matter and the fibrous components of the ration.

The weight loss of the animals consuming CT may be related to the increase of $45 \%$ in the energy loss in feces and the reduction of $30 \%$ in nitrogen retention, when goats were fed $5.7 \mathrm{~g}$ of CT per kilogram of DM (Bhatta et al $2013^{\mathrm{b}}$ ).

On the other hand an increase in milk production has been recorded in several experiments. Anantasook et al (2014) showed an increase of $10 \%$ in milk yield of cows fed 88 $\mathrm{g}$ of CT per kg DM. And Dey et al (2014) with crossbred cows fed $1.5 \%$ condensed tannins per $\mathrm{kg} \mathrm{DM}$ were able to increase milk yield by $24.7 \%$ compared to cows without $\mathrm{CT}$ in the ration. In this sense, under tropical conditions the widely available tropical shrub L. leucocephala provided at levels of 30 and $45 \%$ on the DM of ration was able to increase milk yield up to 6.64 and $7.76 \mathrm{~kg}$ per cow per day respectively compared to cows $(5.11 \mathrm{~kg}$ milk/day) fed only a grass ration (P. purpureum) (Ruiz-González 2013).

In spite of a positive effect of CT on milk production, some findings have been reported a reduction in milk production. At this respect Grainger et al (2009) found that when they supplemented cows with $244 \mathrm{~g}$ of CT per day, milk production was decreased by $29.7 \%$. This reduction was related to a decrease on $26.4 \%$ in feed intake induced by CT. On the other hand, Fagundes et al (2014) evaluated the inclusion of $25 \%$ of $F$. macrophylla with a concentration of $105 \mathrm{~g} / \mathrm{kg} \mathrm{DM}$ of CT in the ration of goats, and found a reduction of $10.8 \%$ in voluntary feed intake; however, they did not find any difference in milk yield.
Due to the variation in the effect of CT both under in vitro as under in vivo conditions, on rumen microorganisms, patterns of rumen fermentation, emissions of $\mathrm{CH}_{4}$ and productive performance, it is advisable to continue performing experiments on the effect of CT, specific doses given, and to explore the effect of molecular weight of condensed tannins on the production of $\mathrm{CH}_{4}$ in the rumen as well as to determine the effect of CT on energy retention in the body and on the possible increase in added value of ruminant products.

\section{CONCLUSION}

Even when the specific effect of condensed tannins on the reduction of $\mathrm{CH}_{4}$ production in the rumen is still relatively unclear, it has been well established that condensed tannins have the ability to reduce the population of protozoa and methanogens in the rumen, furthermore, they reduce digestibility and alter the pattern of volatile fatty acids in the rumen, reducing the molar proportion of acetic acid and increasing propionic acid. In general, both under in vitro as under in vivo conditions, condensed tannins have the ability of reduce the emissions of enteric $\mathrm{CH}_{4}$, and improve the use of feed energy, which in turn may increase ruminant performance (i.e. weight gain and milk yield).

\section{ACKNOWLEDGEMENTS}

The senior author is would like to thank CONACYT-Mexico for granting a $\mathrm{PhD}$ scholarship for the Faculty of Veterinary Medicine and Animal Science, University of Yucatan, Merida, Mexico.

\section{REFERENCES}

Anantasook N, M Wanapat, A Cherdthong, P Gunun. 2014. Effect of tannins and saponins in Samanea saman on rumen environment, milk yield and milk composition in lactating dairy cows. J Anim Physiol Nutr DOI: 10.1111/jpn.12198.

Andrade-Rivero E, A Martínez-Campos, O Castelán-Ortega, J RíosQuezada, Y Pacheco-Ortege, J Estrada-Flores. 2012. Methane production utilizing taniniferous plants as substrate in ruminal fermentation in vitro and effect of phenolic extracts on ruminal microflora. Trop Subtrop Agroecosyt 15, 301-312.

Animut G, R Puchala, AL Goetsch, AK Patra, T Sahlu, VH Varel, J Wells. 2008. Methane emission by goats consuming diets with different levels of condensed tannins from lespedeza. Anim Feed Sci Tech 144, 212-227.

Ayala-Monter MA. 2013. Inclusión de taninos en la dieta de ovinos en finalización: respuesta en la calidad de la carne. Tesis, Colegio de Posgraduados, Montecillos, México.

Barry TN, SJ Duncan.1984. The role of condensed tannins in the nutritional value of Lotus pedunculatus for sheep. Brit J Nutr 51, 485-491.

Bezerra L, J Sarmento, S Neto, N Paula, R Oliveira, W Rêgo. 2013. Residual feed intake: a nutritional tool for genetic improvement. Trop Anim Health Prod 45, 1649-1661.

Bhatta R, O Enishi, Y Yabumoto, I Nonaka, N Takusari, K Higuchi, K Tajima, A Takenaka, M Kurihara. 2013ª . Methane reduction and energy partitioning in goats fed two concentrations of tannin from Mimosa spp. J Agric Sci Camb 151, 119-128. 
Bhatta R, M Saravanan, L Baruah, KT Sampath, CS Prasad. 2013 Effect of plant secondary compounds on in vitro methane, ammonia production and ruminal protozoa population. J Appl Microbiol $115,455-465$.

Brouwer E. 1965. Report of subcommittee on constants and factors. In: Blaxter KL (ed). Proceedings of the $3^{\text {th }}$ Symposium on energy Metabolism. Academic Press, London, UK, Pp 441-443.

Burke JM, JE Miller, TH Terrill, JA Mosjidis. 2014. The effects of supplemental Sericea lespedeza pellets in lambs and kids on growth rate. Livst Sci 159, 29-36.

Carulla JE, M Kreuzer, A Machmüller, HD Hess. 2005. Supplementation of Acacia mearnsii tannins decreases methanogenesis and urinary nitrogen in forage-fed sheep. Aust J Agr Res 56, 951-969.

Chung YH, EJ Mc Geough, S Acharya, TA McAllister, SM McGinn, OM Harstad, KA Beauchemin. 2013. Enteric methane emission, diet digestibility, and nitrogen excretion from beef heifers fed sainfoin or alfalfa. J Anim Sci 91, 4861-4874.

Cieslak A, P Zmora, E Pers-Kamczyc, M Szumacher-Strabel. 2012. Effects of tannins source (Vaccinium vitis idaea L.) on rumen microbial fermentation in vivo. Anim Feed Sci Tech 176, 102-106.

Czerkawski JW. 1986. An introduction to rumen studies. Pergamon Press, New York, USA

Delgado D, J Galindo, R González, N González, I Scull, L Dihigo, J Cairo, A Aldama, O Moreira. 2012. Feeding of tropical trees and shrub foliages as a strategy to reduce ruminal methanogenesis: studies conducted in Cuba. Trop Anim Health Prod 44, 1097.

Dey A, and PS De. 2014. "Influence of Condensed Tannins from Ficus bengalensis Leaves on Feed Utilization, Milk Production and Antioxidant Status of Crossbred Cows". Asian Australas J Anim Sci 27, 342-348.

Dias-Moreira G, PM Tavares-Lima, B Oliveira-Borge, O Primavesi, C Longo, C McManu, A Abdalla, H Louvandini. 2013. Tropical tanniniferous legumes used as an option to mitigate sheep enteric methane emission. Trop Anim Health Prod 45, 879-882.

Eckard RJ, C Grainger, CAM Klein. 2010. Options for the abatement of methane and nitrous oxide from ruminant production: a review. Livest Sci 130, 47-56.

Fagundes GM, EC Modesto, CEM Fonseca, HRP Lima, JP Muir. 2014. Intake, digestibility and milk yield in goats fed Flemingia macrophylla with or without polyethylene glycol. Small Rumin. Res 116, 88-93.

Galindo J, N González, D Delgado, A Sosa, Y Marrero, R González, AI Aldama, O Moreira. 2008. Efecto modulador de Leucaena leucocephala sobre la microbiota ruminal. Zootecn Trop 26, 249-252.

Gerber PJ, H Steinfeld, B Henderson, A Mottet, C Opio, J Dijkman, A Falcucci, G Tempio. 2013. Climate change through livestock - A global assessment of emissions and mitigation opportunities. Food and Agriculture Organization of the United Nations, Rome, Italy.

Goel G, AK Puniya, CN Aguilar, K Singh. 2005. Interaction of gut microflora with tannins in feeds. Naturwissenschaften 92, 497-503.

Goel G, HPS Makkar, K Becker. 2008. Effects of Sesbania sesban and Carduus pycnocephalus leaves and Fenugreek (Trigonella foenumgraecum $L$.) seeds and their extracts on partitioning of nutrients from roughage and concentrate based feeds to methane. Anim Feed Sci Tech 147, 72-89.

Goel, G, AK Puniya, K Singh. 2007. Phenotypic characterization of tannin-protein complex degrading bacteria from faeces of goat. Small Rumin Res 69, 217-220.

Gómez-Castro H, J Nahed-Toral, A Tewolde, R Pinto-Ruiz, J LópezMartínez. 2006. Áreas con potencial para el establecimiento de árboles forrajeros en el centro de Chiapas. Téc Pecu Méx 44, 219-230.

Grainger C, T Clarke, MJ Auldist, KA Beauchemin, SM McGinn, GC Waghorn, RJ Eckard. 2009. Potential use of Acacia mearnsii condensed tannins to reduce methane emissions and nitrogen excretion from grazing dairy cows. Can J Anim Sci 89, 241-251.

Gurbuz Y. 2009. Efectos del contenido de taninos condensados de algunas especies de leguminosas en la emisión de gas metano. Rev Cubana Cienc Agríc 43, 265-273.
Hales KE, TM Brown-Brandl, HC Freetly. 2014. Effects of decreased dietary roughage concentration on energy metabolism and nutrient balance in finishing beef cattle. J Anim Sci 92, 264-271.

Harborne JB. 1993. Introduction to Ecological Biochemistry. Academic Press, London, UK.

Hassanat F, C Benchaar. 2013. Assessment of the effect of condensed (acacia and quebracho) and hydrolysable (chestnut and valonea) tannins on rumen fermentation and methane production in vitro. J Sci Food Agr 93, 332-339.

Hatew B, CH Carbonero, E Stringano, LF Sales, LMJ Smith, I MuellerHarvey, WH Hendriks, WF Pellikaan. 2014. "Diversity of condensed tannin structures affects rumen in vitro methane production in sainfoin (Onobrychisviciifolia) accessions". Grass and Forage Sci 70, 474-490.

Huang XD, JB Liang, HY Tan, R Yahya, YW Ho. 2011. Effects of Leucaena condensed tannins of differing molecular weights on in vitro $\mathrm{CH}_{4}$ production. Anim Feed Sci Tech 166-167, 373-376.

Jayanegara A, E Wina, CR Soliva, S Marquardt, M Kreuzer, F Leiber. 2011. Dependence of forage quality and methanogenic potential of tropical plants on their phenolic fractions as determined by principal component analysis. Anim Feed Sci Tech 163, 231-243.

Jayanegara A, F Leiber, M Kreuzer. 2012. Meta-analysis of the relationship between dietary tannin level and methane formation in ruminants from in vivo and in vitro experiments. J Anim Physiol Nutr 96, 365-375.

Johnson KA, DE Johnson. 1995. Methane emissions from cattle. J Anim Sci 73, 2483-2492.

Karus TEC, Z Yu, CM Preston, RA Dahigren, RJ Zasoki. 2003. Linking chemical reactivity and protein precipitation to structural characteristics of foliar tanins. J Chem Ecol 29, 703-730.

Kennedy PM, E Charmley. 2012. Methane yields from Brahman cattle fed tropical grasses and legumes. Anim Prod Sci 52, 225-239.

Kittelmann S, PH Janssen. 2011. Characterization of rumen ciliate community composition in domestic sheep, deer, and cattle, feeding on varying diets, by means of PCR-DGGE and clone libraries. Fems Microbiol Ecol 75, 468-481.

Kumar R, M Singh. 1984. Tannins: their adverse role in ruminant nutrition. J Agr Food Chem 32, 447-453.

Kumar S, P Choudhury, M Carro, G Griffith, S Dagar, M Puniya, S Calabro, S Ravella, T Dhewa, R Upadhyay, S Sirohi, S Kundu, M Wanapat, A Puniya. 2014. New aspects and strategies for methane mitigation from ruminants. Appl Microbiol Biotechnol 98, 31-44.

Martin C, DP Morgavi, M Doreau. 2010. Methane mitigation in ruminants: from microbe to the farm scale. Animal 4, 351-365.

McMichael AJ, JW Powles, CD Butler, R Uauy. 2007. Food, livestock production, energy, climate change, and health. Lancet 370, 1253-1263.

McSweeney CS, B Palmer, R Bunch, DO Krause. 2001. Microbial interactions with tannins: nutritional consequences for ruminants. Anim Feed Sci Tech 91, 83-93.

Min BR, WE Pinchak, RC Anderson, JD Fulford, R Puchala. 2006. Effects of condensed tannins supplementation level on weight gain and in vitro and in vivo bloat precursors in steers grazing winter wheat. J Anim Sci 84, 2546-2554.

Min BR, WE Pinchak, K Hernández, C Hernández, ME Hum, E Valencia, JD Fulford. 2012. Effects of plant tannin supplementation on animal response and in vivo ruminal bacterial populations associated with bloat in heifers grazing wheat forage. The Professional Animal Scientist 28, 464-472.

Min BR, S Solaiman, R Shange, JS Eun. 2014. Gastrointestinal bacterial and methanogenic archaea diversity dynamics associated with condensed tannin-containing pine bark diet in goats using 16S rDNA amplicon pyrosequencing. Int J Microbiol 11.

Moss AR, JP Jouany, J Newbold. 2000. Methane production by ruminants: its contribution to global warming. INR EDP Sciences. Ann Zootech 49, 231-253.

Murgueitio ER, JD Chará, AJ Solarte, F Uribe, C Zapata, JE Rivera. 2013. Agroforestería Pecuaria y Sistemas Silvopastoriles Intensivos (SSPi) para la adaptación ganadera al cambio climático con sostenibilidad. Rev Colomb Cienc Pecu 26, 313-316. 
Naumann HD, LO Tedeschi, JP Muir, BD Lambert, MM Kothmann. 2013. Effect of molecular weight of condensed tannins from warmseason perennial legumes on ruminal methane production in vitro. Biochem Syst Ecol 50, 154-162.

Patra AK. 2010. Meta-analyses of effects of phytochemicals on digestibility and rumen fermentation characteristics associated with methanogenesis. J Sci Food Agr 90, 2700-2708.

Perevolotsky A. 1994. Tannins in Mediterranean woodlands species: lack of response to browsing and thinning. Oikos 71, 333-340.

Priolo A, GC Waghorn, M Lanza, L Biondi, P Pennisi. 2000. Polyethylene glycol as a means for reducing the impact of condensed tannins in carob pulp: effects on lamb growth, performance and meat quality. J Anim Sci 78, 810-816.

Puchala R, BR Min, AL Goetsch, T Sahlu. 2005 The effect of a condensed tannin-containing forage on methane emission by goats. J Anim Sci 83, 182-186.

Puchala R, G Animut, AK Patra, GD Detweiler, JE Wells, VH Varel, T Sahlu. 2012 ${ }^{\mathrm{a}}$. Methane emissions by goats consuming Sericea lespedeza at different feeding frequencies. Anim Feed Sci Tech $175,76-84$

Puchala R, G Animut, AK Patra, GD Detweiler, JEWells, VH Varel, T Sahlu, AL Goetsch. 2012 ${ }^{\mathrm{b}}$. Effects of different fresh-cut forages and their hays on feed intake, digestibility, heat production, and ruminal methane emission by Boer $\times$ Spanish goats. J Anim Sci 90, 2754-2762.

Reed JD. 1995. Nutritional toxicology of tannins and related polyphenols in forage legumes. J Anim Sci 73, 1516-1528.

Robinson TP, PK Thornton, G Franceschini, RL Kruska, F Chiozza, A Notenbaert, G Cecchi, M Herrero,M Epprecht, S Fritz, L You, G Conchedda, L See. 2011. Global livestock production systems. Food and Agriculture Organization of the United Nations and International Livestock Research Institute, Rome, Italy.
Rodríguez R, A Britos, N Rodríguez-Romero, M Fondevila. 2011. Effect of plant extracts from several tanniferous browse legumes on in vitro microbial fermentation of the tropical grass Pennisetum purpureum. Anim Feed Sci Tech 168, 188-195.

Ruiz-Gonzales A. 2013. Balance de nitrógeno y composición de la leche de vacas alimentadas con Leucaena leucocephala. Tesis de maestría. Universidad Autónoma de Yucatán. Mérida, Yucatán, México.

Soltan YA, AS Morsy, SMA Sallam, H Louvandini, AL Abdalla. 2012. Comparative in vitro evaluation of forage legumes (prosopis, acacia, atriplex, and leucaena) on ruminal fermentation and methanogenesis. J Anim Feed Sci 21, 759-772.

Soltan, YA, AS Morsy, SMA Sallam, RC Lucas, H Louvandini, M Kreuzer, AL Abdalla. 2013. Contribution of condensed tannins and mimosine to the methane mitigation caused by feeding Leucaena leucocephala. Arch Anim Nutr 67, 169-184.

Tan HY, CC Sieo, N Abdullah, JB Liang, XD Huang, YW Ho. 2011. Effects of condensed tannins from Leucaena on methane production, rumen fermentation and populations of methanogens and protozoa in vitro. Anim Feed Sci Tech 169, 185-193.

Tavendale MH, LP Meagher, D Pacheco, N Walker, GT Attwood, $\mathrm{S}$ Sivakumaran. 2005. Methane production from in vitro rumen incubations with Lotus pedunculatus and Medicago sativa, and effects of extractable condensed tannin fractions on methanogenesis. Anim Feed Sci Tech 123-124, 403-419.

Tiemann TT, CE Lascano, HR Wettstein, AC Mayer, M Kreuzer, HD Hess. 2008. Effect of the tropical tannin-rich shrub legumes Calliandra calothyrsus and Flemingia macrophylla on methane emission and nitrogen and energy balance in growing lambs. Anim 2, 790-799.

Wischer G, AM Greiling, J Boguhn, H Steingass, M Schollenberger, K Hartung, M Rodehutscord. 2014. Effects of long-term supplementation of chestnut and valonea extracts on methane release, digestibility and nitrogen excretion in sheep. Anim 8, 938-948. 